\title{
Impressions of the most comprehensive urban regeneration project implemented in Istanbul
}

\author{
S. Turgut \\ Yildiz Technical University, Faculty of Architecture, \\ Department of Urban \& Regional Planning, Istanbul, Turkey
}

\begin{abstract}
The urban regeneration efforts in the district of Kucukcekmece will be analyzed within the scope of the problems described. Kucukcekmece, one of the pioneer districts of Istanbul, has been trying a new and different regeneration process in Turkey. The settlement area, having quite significant potential within Istanbul as well as so many intensive and complicated problems, entered an active process in terms of planning and initiated efforts that could also serve as a locomotive for the planning efforts of Istanbul. However, institutional relations, disintegration of planning and weakening of coordination and organization processes, disconnection between stages and processes of planning, the new but problematic legal structure defined within the scope of legal revisions made within the scope of the process of joining EU and technical deficiencies create significant threats for the success of the system. Within the scope of the example that will be analyzed within this framework, the stages of planning and implementation, blockages and the factors threatening the system will be analyzed against the expectations of the city and especially of the district of Kucukcekmece. The opportunities and threats of planning and planning management will be analyzed; proposals and strategies will be discussed.
\end{abstract}

Keywords: urban regeneration, urban strategies, planning management, management of urban regeneration, Küçükçekmece regeneration projects.

\section{Introduction}

Being located in the crossroads of Asia and Europe, Istanbul has been one of the most important centers of civilization and culture for the 20 centuries of its existence. The city embraced many civilizations and served as the capital city of 
three major empires. However, particularly as a result of migration and policies that have encouraged migration for the last 60 years, Istanbul started to experience a dangerous process of losing its potentials and values. Having failed to take the required measures, set policies and implement a conscious planning process against this migration wave, the city has undergone an unconscious "growth", and lived through a "monstrous" enlargement process to become an unhealthy and unbalanced metropolis. With urban population growth rate higher than the national average, the city has grown in the form of an "oil stain" and illegal settlement and unplanned growth have become the most important problems.

One of the leading districts of Istanbul Metropolitan is the Kucukcekmece District to the west of Kucukcekmece Lake. Historical development and the change process of Kucukcekmece go back to the Republican era. Having started with small settlements around Avcilar and Kucukcekmece from 1920 through 1950, the reconstruction activities accelerated from 1950-1970 and rapidly spread over Avcılar, Sefaköy and Halkalı region. This uncontrolled spread gained further momentum after 1970. With the lack of organized urban policies, plans, management and supervision processes against this development, the city rapidly experienced illegal solution attempts which have become the determinant of the settlement. Right on the perimeter of the district, illegal residential areas with no infrastructure, transportation connections or social facilities have rapidly grown.

\section{Ayazma-Tepeüstü sub-region}

With a population of 800,000 , Kucukcekmece district features different residential textures and most of them are unplanned and illegal. Being located between the north of TEM, the international motorway on the west side of city and the east of Atatürk Olympic Stadium, Ayazma-Tepeüstü Sub-Region is perhaps the most characteristic shantytown among others. This is a Sub-Region that contains mostly single-storey buildings constructed illegally on treasury land with no technical or social infrastructure and that face serious problems in terms of physical and socio-economical conditions due to social exclusion by being one of the depression areas. The region is also located on a first-degree earthquake zone.

This region features a property texture that consists of foundation, TEDAS, provincial administration and expropriated lands with 50\% personal and 30\% treasury possession on an area of 120 ha. Tepeüstü region occupies an area of 24.6 ha with a $40 \%$ TOKI and treasury, cooperative and personal possession texture. The total possession consists of $44 \%$ private and $56 \%$ public shares. There are a total of 1625 buildings and a total population of 10,675 in both regions. Average family size is 4.5 with an employment rate of $21 \%$.

The region consists of a mainly young population $(38 \%, 0-14)$ with the entire population coming from migration. (Rate of household provider born in Istanbul is $1 \%$.). Of the working population, $78 \%$ is employed in manufacturing industries located in Küçükçekmece and İkitelli. The total monthly income of 
$64 \%$ of the population is under US\$ 500, and 30\% have an income between US\$500-1500. Others do not have a fixed income. That is to say that they do not have a fixed job. In terms of distribution of income, this region is at least $50 \%$ poorer than the rest of Istanbul. (Rate of population with more than 1500 Dollars of income is only $1 \%$.)

\section{Application example: Küçükçekmece District Ayazma-Tepeüstü sub-region Urban Regeneration Project}

Ayazma-Tepeüstü Urban Regeneration Project was first brought into the agenda in 2004 within the scope of transformation of shantytowns within the border of Kucukcekmece Municipality. Ayazma-Tepeüstü was selected as the pilot project region for efforts to produce a solution to areas that are the result of, mostly illegal, settlements in shantytowns, which are quite problematic in terms of socio-economical and physical conditions. With no social or technical infrastructure, and a lack of contemporary settlement and urbanization principles, this region features an excluded and disadvantageous structure in terms of its social profile. Despite being located adjacent to a transportation axis, this region has no safe transportation connections, accommodates people that do not even have official birth records, families with no official marriage bonds living under feudal rules, children without education, physically and mentally disabled people due to a lack of knowledge and health problems, and people with criminal records. Selection of this area was also driven by its proximity to Atatürk Olympic Stadium; with the aim to take the Olympic stadium and the village in its entirety and evacuate this area within the framework of the said activity area. With these acceptances and targets, Kucukcekmece Municipality has become the first to request a series of studies focused on "Urban Regeneration" and started to implement the process with many associated stakeholders. For this purpose, the Metropolitan Municipality, Kucukcekmece Municipality and Mass Housing Administration (TOKI) signed a protocol on 13/06/2004 following the announcement of Ayazma and Tepeüstü Regions as the Urban Regeneration Areas. Following execution of the said protocol and with the responsibility of a modern and social municipality, Kucukcekmece Municipality held the "International Urban Regeneration Symposium" on 27-30 November 2004 with the purpose of discussing the Urban Regeneration from a new perspective, benefiting from international experiences and to find out the problematic points of previous application. In line with the protocol executed as a result of the urban regeneration process, Istanbul Metropolitan Municipality has become the institution that will provide the resources, Mass Housing Administration has become the contractor of new buildings that will be occupied by the regional people and Kucukcekmece Municipality has become the project implementer, as the representative of local administration.

Ayazma and Tepeüstü Regions are located in an area that features important locational potentials for Kucukcekmece District, which may serve the Istanbul Metropolitan Area. The project has been discussed among scientists during the 
said symposium and the workshops thereafter and important contributions have been obtained by both national and international scientists. The first important step following these meetings was the establishment of an "Urban Regeneration Unit" by the Municipality. This unit was organized under Plan-Project Directorate and consisted of urban planners, architects, civil engineers, cartography engineers, computer engineers and GIS experts.

The office completed the identification of the current status and the right holders in Ayazma and Tepeüstü Regions between 27/06/2005 and 21/07/2005. Data gathered from the land and documents collected from the right holders in the region were transferred to digital media via the database and appraisal reports were issued on the basis thereof. Tepeüstü dwellers, who are almost entirely living on a treasury land, accepted the demolition, but the landlords of the region reacted to this claiming that tenants will become right holders as they did not have any title deeds. They tried to prevent distribution of documents to tenants during land works. People of Ayazma region, on the other hand, has caused many problems and disorder claiming that they were not provided with information on any demolition before the start of works. This kind of argument has led to the implementation of this method, which is not transparent. Ayazma region was divided into two groups with different attitudes. One consisted of people living in single-storey shanties and the other consisted of people living in multi-storey apartment buildings.

People living in sheds They welcomed demolition because they wanted to have registered houses but thought that the price appraised by TOKI would not cover the price of their apartments. Families living there thought that they would not fit in mass housing lifestyle and finally they claimed that they are entitled to multiple houses because multiple families lived together.

People living in multi-storey apartment buildings They thought that they would not get the exact value of their houses, they reacted to demolition because they were expecting right of reconstruction and claimed that the houses to be allocated would not be sufficient in terms of square meter space. However, no significant reactions were experienced during the land works. Since the project was started upon "Approval of the Prime Ministry", the decision-making mechanism has become the central administration. This has led to problems in coordination and in prevention of local administration from owning the process in terms of lack of delegation of powers to local administration. Representing the central administration, Istanbul Metropolitan Municipality and Turkish Mass Housing Administration (TOKI) have assumed a decision-making and approving role. Furthermore, this facilitated the solution of legal problems, acceleration of bureaucracy and preparation and approval of reconstruction plans. Istanbul Metropolitan Municipality has played an active role during execution and implementation of the project. TOKI provided the resources for the project. They have undertaken the construction of new residences in Bezirganbahçe where the people will be settled. The administration will assume the ownership of the area after demolition of shanties and start construction of new residences according to the reconstruction plans. As the local administration, Kucukcekmece 
Municipality has played an active role in the entire project process and carried out the implementation of project and established dialogues with the people of region. Land identification, right holder identification, contract execution, ballots, transportation and demolition of shanties are all carried out by using local labor and resources. Following the ballots, the second phase has started to address almost 1100 landlords.

In the meantime, Istanbul Metropolitan Municipality Urban Regeneration Directorate started an Earthquake-Focused Urban Regeneration study in Kucukcekmece District on $02 / 11 / 2005$, and a parallel process has started by awarding the said work to BIMTAŞ, a municipality company. Within the scope of this award, locational strategic planning studies have been started by also partially repeating the works that had been carried out by the district municipality until that date and urban regeneration works will be started in 10 different Sub-Regions upon completion of the said works. Despite the deadline of April 2007, the projects have not been completed yet. Many legal problems have been solved easily because of this being a partnership between governmental institutions. Most importantly, bureaucracy was totally eliminated. This urban regeneration project has been implemented upon the "Prime Ministry Approval" without depending on any laws. However, there were some problems in terms of coordination and ownership of the works. After that, implementation of the social program was started for the Bezirganbahçe Mass Housing Area where the people of Ayazma moved.

\section{Social program for "Bezirganbahçe" - our people}

The social program was named and organized under "Bezirganbahçe Our People Social Program". It is possible to examine the associated works under three main sections - namely, organization, programming and implementation.

The organization unit formed under the R\&D unit of the plan and project directorate of Kucukcekmece Municipality with the expertise and coordination of Urban Planners. It consisted of urban planners, two sociologists, one psychologist, one kindergarten teacher, surveyors, field workers and consultants in relevant fields (medical doctors, sociologists, urban scientists, technical service and expertise instructors, etc). The said project consisted of four main topics and study fields; namely, health, education, employment and personal development. In this context, the main objective was to provide services such as free health scans, vaccinations, diabetic and tension scans, etc. Education was involved in information and awareness studies for different age and gender groups and disadvantaged groups, and was supported with special brochures. Employment was addressed by the opening of vocational courses in different fields with an aim to fill in the gaps in industries in the region (topics based on the requests of the people). Finally, the personal development programs included integration with urban lifestyle, awareness and information, hobbies and social responsibility projects for different age groups and disadvantaged groups. 


\section{Conclusion}

Having been started by Istanbul Kucukcekmece Municipality and shaped with the contributions of academicians, international literature and science, an "urban regeneration" story has reached a certain stage with positive and negative aspects. The main drive of the project was the rehabilitation of illegally structured areas that lack all kinds of modern life infrastructure and design and its redevelopment of the Olympic Village and surroundings. This has been accepted as a flagship project that affects not only Kucukcekmece, but also the entire area of Istanbul in a positive manner. Having been organized coherently from the start of process, Istanbul Metropolitan Planning and Urban Design (IMP) office has undertaken the design works for Ayazma-Tepeüstü region as a result of conflict of authorities and political processes and the study has started to gain new dimensions at this point. During the said design works with almost no coordination, the idea of the Olympic Village has almost been lost and the area has been designed as a residential area that will serve higher income groups. Land surveys and interviews with people during this stage have been carried out by the district municipality with almost no disagreements.

Finally, the people of Ayazma-Tepeüstü were moved to Bezirganbahçe Social Mass Housing area and after that, the people were given services in the fields of personal and social development, vocational, health services, wide and formal education services, support of underprivileged groups, information, awareness, solutions to problems and areas of interest of different age and gender groups in the region.

\subsection{What was expected...?}

It was expected to institutionalize the process and base it on a scientific foundation; establish a unit in the relevant field in order to achieve sustainability, supervision and functionality, create workshops, ensure participation, continuously inform the people, establish and implement a win-win project with the participation of experts from different disciplines; design the evicted area together with Atatürk Olympic Stadium as an Olympic Village that will serve Istanbul under an integrated concept; construct the new social mass housing area in Bezirganbahçe with the right and quality construction and design processes; transform the area into an exemplary model for the entire Kucukcekmece district and Istanbul; support the social structure and start an intense program with the aim to ensure sustainability of the entire system in terms of physical locations by accepting that the top two important phases of urban regeneration form an integrated structure.

\subsection{What has happened...?}

Academic discussion platforms are established and ideas are exchanged with relation to the process, Municipality has organized an "Urban Regeneration" unit where the relevant projects and processes will be determined. The office was 
supported by experts from different fields, people were continuously informed, requests are evaluated, a win-win project was realized with the exception of tenants, 943 units are moved to new houses in Bezirganbahçe, 11 units of tenants could not have any rights and their housing problems were not solved (district governor and municipality offered the said tenants a chance for employment and reimbursement of two-year tenancy but these people are still living in tents in the demolition area), and IMP has implemented an additional urban design project on the demolition area. The area was not designed as an Olympic Village. The mass housing constructed by TOKI does not conform to urban design principles with construction quality well below the standards and there is no possibility to correct this situation. The project has been declared unsuccessful due to political pressures of interest groups, difficulties during participation processes and failure of NGOs to manage the process correctly; and the entire process is introduced as a defective process. The project has experienced delays and become a noneconomic project in terms of investments with the participation of Istanbul Metropolitan Municipality and other authorities (such as BİMTAŞ) in the process. Several studies have been started but none has produced any results. This led to an important obstacle before the effectiveness of the district municipality. Principally, the main idea was to create a project that will address all right holders and tenants in terms of legal processes and the required conditions; but, models created particularly by legal advisors and the legal restrictions prevented any implementation towards providing the tenants with rights. The widest Social Development Program has been organized under the name of "Our People Social Development Program". However, this project could not be promoted sufficiently. Despite all these, the project has developed an exemplary program and organization.

\section{References}

[1] Atkinson, R., Urban Regeneration, Partnerships and Community Participations: Lessons from England, Istanbul Urban Regeneration Symposium, İstanbul, 2004, pp: 117-130

[2] İstanbul Metropolitan Planning Office, 1/100.000 İstanbul Master Plan Report, İMP, İstanbul 2007.

[3] Küçükçekmece Municipality, Bezirganbahçe Our People Social Programme Report, İstanbul, 2008

[4] Küçükçekmece Municipality, Küçükçekmece Ayazma -Tepeüstü Sub Region Area Analytical Survey, İstanbul 2004

[5] Turgut, S., Cactaş, C., E., Küçükçekmece Spatial Plan Report, Küçükçekmece Municipality, İstanbul 2006. 